\title{
Magdalena Josefa Svatopluka Machara w tłumaczeniu Zofii Trzeszczkowskiej. „Bratnia kontrola” Zenona Przesmyckiego - świadectwo problemów przekładu zachowane w korespondencji
}

\author{
Aleksandra Beasińska \\ (Instytut Badań Literackich PAN, Warszawa)
}

Z zachowanych 99 listów Zofii Trzeszczkowskiej (piszącej pod pseudonimem Adam M-ski, Adam Mańkowski) do Zenona Przesmyckiego można odtworzyć losy tłumaczeń kilku utworów dokonanych z języków: hiszpańskiego, francuskiego, prowansalskiego, a także prześledzić wzmianki o przekładach z języka czeskiego. W tym ostatnim języku tłumaczka próbowała przyswoić polskiemu czytelnikowi Magdalenę Josefa Machara - poemat, który został opublikowany w I893 roku.

Miriam, świetnie orientujący się w literaturze światowej, inspirował Trzeszczkowską do przekładu prac, które go interesowały i które uważał za cenne dla naszej kultury. O losach translatorskich Magdaleny wiemy stosunkowo niewiele, tym razem inicjatywa nie leżała po jego stronie.

Pierwsza wzmianka Trzeszczkowskiej na ten temat w liście do Miriama pochodzi z 5 listopada I896 roku. Możliwe, że asumptem do zainteresowania się twórczością Machara był artykuł Leona Wasilewskiego popularyzujący najnowsze zdobycze literatury czeskiej, zamieszczony 6 czerwca I896 roku w regularnie czytanym przez poetkę „Głosie”. Problematyka Magdaleny skupia się wokół tematów nurtujących Trzeszczkowską - kwestii społecznej i kobiecej. Tytułowa bohaterka, podobnie jak biblijna Maria Magdalena, pod wpływem skomplikowanych okoliczności trafia

1 L. Wasilewski, Ze Stowiańszczyzny. Stosunki literackie Czech wspótczesnych, „Głos” 1896, nr 23, s. 535-537. 
do domu publicznego i wiedzie los nierządnicy. Młody człowiek imieniem Jerzy, kierując się wyższymi pobudkami, postanawia wydobyć ją z tej trudnej sytuacji i oddać pod opiekę swej ciotki. Jednak uprzedzania warstw mieszczańskich i ich obłudna moralność z czasem zaczynają doskwierać młodzieńcowi, który przez swój szlachetny czyn został narażony na liczne nieprzyjemności. W tych okolicznościach miejsce, z którego bohaterka przybyła, zaczęło jawić się jej jako oaza ciszy i spokoju, zaś paradoksalnie nowy dom, w którym miała doznać wyzwolenia - stał się piekłem. Kobieta postanawia więc zakończyć swoje cierpienia i popełnić samobójstwo.

Jak zauważa Antoni Lange - autor przedmowy do przekładu Trzeszczkowskiej - ,jest to powieść ironiczna, pesymistyczna, demaskująca obłudę: w tym otoczeniu grzesznik nawrócić się nie może”2. Opowieść o miłości zamożnego młodzieńca do prostytutki doskonale odnosiła się do sytuacji poetki, która ukrywając się pod pseudonimem, tłumaczyła skandalizujące dla swego konserwatywnego otoczenia utwory, a krytyka Machara uderzała w prowincjonalną „ciasnotę pojęć”. Tak aktualna tematyka sprawiła, że Magdalena należała do grupy utworów - jak zwykła mawiać Trzeszczkowska - „przypadających do serca”, a co za tym idzie, poetka dokonała przekładu w bardzo krótkim czasie, bowiem już rok później, 8 stycznia I898 roku pisała Miriamowi o zakończeniu swej pracy. Należy dodać, że portugalski epos Luzyjady tlumaczyła dziesięć lat, zaś prowansalski poemat Mireio - lat siedem.

„Znajomość moja czeszczyzny nietęga” - przyznała wprost w liście z 5 marca I898 roku. Mimo że obawiała się niedokładności przekładu, „bardzo by się bratnia kontrola [mu - A. B.] przydała”, to jednak rękopisu z tłumaczeniem do sprawdzenia nie mogła przesłać - czas naglił. Obiecała redaktorowi „Głosu” Zygmuntowi Wasilewskiemu, że wiosną 1898 roku odda gotowy rękopis. W tej sytuacji tłumaczka sporządziła jedynie wykaz trudności przekładowych i i 9 lutego I898 roku wysłała go Przesmyckiemu, „starszemu Czechowi” do konsultacji. Materiał ten, stanowiący źródło obecnego artykułu ${ }^{4}$, dokładnie odtwarza nie tylko problemy translatorskie Trzeszczkowskiej, ale również dokumentuje wskazówki samego Miriama i - co wydaje się najistotniejsze - jego wpływ na ostateczny kształt przekładu Magdaleny. Wiadomo, że sugestie Przesmyckiego, który tłumaczył m.in. poezje Jaroslava Vrchlickiego, okazały się pomocne:

\section{\Uwagi Twoje są bardzo słuszne; zdradliwe podobieństwo wyrazów,} przy znaczeniu różnym w naszym a czeskim języku, niejednokrotnie

2 A. Lange, Z literatury czeskiej. („Magdalena”J. Machara przetożyt Adam M-ski),„Gazeta Polska”1899, nr 254, s. 2.

3 Na przykład w liście do Przesmyckiego z 18 sierpnia 1890 roku, BN sygn. 2864: „Co piszesz o przekładzie Mireio - bardzo mi do serca przypada".

4 Wykaz trudności przekładowych został zamieszczony poniżej w formie tabelki. 
zauważyłem ${ }^{5}$. [...] przed laty bawiłem w Czechach kilka tygodni, zdobyłem sobie słowniki czesko-francuskie i jakoś wszędzie z ludźmi dogadać się mogłem, potem trochę czytałem i próbowałem tłumaczyć drobiazgi (Hálek), większą robotą pierwszą jest Magdalena ${ }^{6}$.

Utwór ukazał się w Warszawie w I90o roku nakładem redakcji „Głosu”. I tym razem przekład nie spełniał oczekiwań Trzeszczkowskiej, gdyż Magdalena została znacznie skrócona. Częściowo było to spowodowane względami cenzuralnymi - usunięto między innymi buntownicze wypowiedzi rewolucjonisty oraz sceny w domu publicznym - a częściowo samowolą redakcji:
\Wydano mi ją niegodziwie; już to ja mam do tego szczęście wyjątkowe. Oddałem rękopis Wasilewskiemu za bezcen (r[ubli] s[rebrnych] Ioo), z tym warunkiem, że ostatnią korektę będę robił sam; umowa stanę- ła, ale kiedy książka była już w druku, piszą mi nagle, że w drukarni czcionek mają za mało, więc czekać na korektę nie mogę. W czas się opatrzyli... Jak na tym wyszedłem, przekonasz się; na moją wymówkę odpowiedzieli, że ani litery nie opuścili sami, tylko cenzura powy- kreślała, na dowód czego mieli mi przysłać pokreślony egzemplarz z cenzury. Jakoś dotąd czekam nadaremnie... ${ }^{7}$

Przekład Magdaleny był ostatnim tłumaczeniem Trzeszczkowskiej. Po nim nosiła się jeszcze z zamiarem przełożenia innych utworów: między innymi poematów Lon Rose i Nerto Frédérica Mistrala, Confiteor Josefa Machara, Epopei karolińskiej Juliusa Zeyera. Niestety, zamierzenia te nie wyszły poza ramy pomysłów. Liczne przeciwności losu, jak utrata majątku, dwukrotny pożar, niespełniona miłość, oddaliły ją od realizacji planów. Stało się więc wreszcie to, czego już wcześniej się obawiała, wyznając pod koniec 1896 roku: „Sam tworzyć nie mogę, coś zerwało się we mnie”8.

Przytoczony wykaz, załączony do listu z dnia I9 lutego I898 roku, znajduje się w korespondencji Zenona Przesmyckiego w Bibliotece Narodowej pod sygnaturą 2864. Jest on pisany przez Trzeszczkowską czarnym atramentem, zaś odnotowane w przypisach notatki Przesmyckiego - ołówkiem. Zachowano wszystkie podkreślenia autorów. Nieczytelny tekst zaznaczono kreskami w nawiasie [--]. Wszelkie

5 Autorka w korespondencji podpisywanej „Adam Mańkowski” (Adam M-ski) niemal zawsze konsekwentnie zachowuje formy męskie czasowników.

6 Adam M-ski [Zofia Trzeszczkowska] do Zenona Przesmyckiego, 17 marca 1898, BN sygn. 2864.

7 Ibidem, 27 stycznia $1900 \mathrm{r}$.

8 Ibidem, [brak daty dziennej] koniec $1896 \mathrm{r}$. 
informacje w nawiasach kwadratowych pochodzą od edytora. Ortografię i interpunkcję zmodernizowano zgodnie $\mathrm{z}$ obowiązującymi obecnie zasadami.

Papier rękopisów jest jasnobeżowy w linię, bibułkowy, o formacie $135 \times 217 \mathrm{~mm}$, zajmuje karty od 249 do 250.

\section{BibLIOGRAFIA:}

Koc B., Miriam. Opowieść biograficzna, Warszawa 1890;

Lange A. do Adama M-skiego [Z. Trzeszczkowskiej], w: A. Lange, Listy zebrane, wybór, wstęp, oprac. A. Kasica, Kraków 2013;

Lange A., Z literatury czeskiej. („Magdalena” J. Machara przetożyt Adam M-ski), „Gazeta Polska” 1899, nr 254;

Machar J., Magdalena, Praha 1887;

Machar J., Magdalena, tłum. z czes. Adam M-ski, z przedm. A. Langego, Warszawa 1900;

M-ski Adam [Zofia Trzeszczkowska] do Zenona Przesmyckiego, BN sygn. 2864.

Olech B., Nieznane listy Zofii Trzeszczkowskiej do Miriama, w: Sztuka pisania. O liście polskim w wieku XIX, pod red. J. Sztachelskiej i E. Dąbrowicz, Białystok 2000, s. 401-416;

Święch J., Twórczość poetycka Zofii Trzeszczkowskiej (Adama M-skiego) [niepublikowana rozprawa doktorska obroniona pod kierunkiem prof. dr J. Garbaczowskiej], 1969, Biblioteka UMCS;

Wasilewski L., Ze Stowiańszczyzny. Stosunki literackie Czech wspótczesnych, „Głos” 1896, nr 23.

SŁowa Klucze: Zofia Trzeszczkowska (Adam M-ski), Magdalena, Josef Machar, Zenon Przesmycki, przekład, korespondencja

\section{Aleksandra B€asińska}

Josef Svatopluk Machar's Magdalena in translation by Zofia Trzeszczkowska. Zenon Przesmycki's "soulmate's control”

The paper presents the circumstances of translating Josef Svatopluk Machar's Magdalena by Zofia Trzeszczkowska (Adam M-ski). The translator had prepared a list of questions which she sent to an "Old Czech" - Zenon Przesmycki for consultation as she faced difficulties in rendering the verses into Polish. The material is a source of information of poet's language capacity, and it also documents hints given by Miriam himself (drafted just above the translator's questions), and thereby his influence on the final version of Magdalena in the Polish language.

Keywords: Zofia Trzeszczkowska (Adam M-ski), Magdalena, Josef Machar, Zenon Przesmycki, translation, correspondence 